\title{
Synthetic paclitaxel-octreotide conjugate reverses the resistance of paclitaxel in A2780/Taxol ovarian cancer cell line
}

\author{
YANG SHEN $^{1}$, XIAO-YU ZHANG ${ }^{1}$, XI CHEN $^{1}$, LI-LI FAN ${ }^{1}$, MU-LAN REN ${ }^{1}$, \\ YONG-PING WU ${ }^{2}$, KENNETH CHANDA ${ }^{3}$ and SHI-WEN JIANG ${ }^{4,5}$ \\ ${ }^{1}$ Department of Obstetrics and Gynecology, Zhongda Hospital, School of Medicine, \\ Southeast University; ${ }^{2}$ Jiangsu Provincial Institute of Materia Medica, Nanjing, Jiangsu 210009, P.R. China; \\ ${ }^{3}$ Department of Obstetrics and Gynecology, University of Zambia, University Teaching Hospital, Lusaka, Zambia; \\ ${ }^{4}$ Department of Obstetrics and Gynecology, The Second Affiliated Hospital and Yuying Children's Hospital of \\ Wenzhou Medical University, Wenzhou, Zhejiang 325027, P.R. China; ${ }^{5}$ Department of Biomedical Science, \\ Mercer University School of Medicine, Savannah, GA 31404, USA
}

Received May 25, 2016; Accepted October 18, 2016

DOI: $10.3892 /$ or.2016.5260

\begin{abstract}
The high mortality of ovarian cancer is partly due to the frequent resistance of ovarian cancer to current chemotherapy agents such as paclitaxel and platinum. Somatostatin analogue (SSTA) has been shown to inhibit the proliferation of some tumors through binding to somatostatin receptor (SSTR) and activation of Ras-, Rapl- and B-Raf-dependent extracellular signal-regulated kinase 2 (Erk2). It was reported that paclitaxeloctreotide conjugate (POC) exhibited enhanced tumor growth inhibition with reduced toxicity. In the present study, we prepared the POC and investigated its effects and mechanism for the reversal of drug resistance in paclitaxel-resistant ovarian cancer cell line. We demonstrated that treatment with POC led to more cell apoptosis than either paclitaxel or octreotide (OCT) alone. Moreover, the expression of multidrug resistance 1 (MDR1) and vascular endothelial growth factor (VEGF) mRNA, and protein decreased in a dose-dependent manner while the expression of SSTR remained stable following treatment with POC. Although the exact action, in vivo effects and pharmacologic kinetics of POC remain to be investigated, we have demonstrated the feasibility for the synthesis of POC, and more significantly, provided a potential approach to overcome
\end{abstract}

Correspondence to: Yang Shen, Department of Obstetrics and Gynecology, Zhongda Hospital, Southeast University, Nanjing, Jiangsu 210009, P.R. China

E-mail: shenyang0924@sina.cn

Shi-Wen Jiang, Department of Obstetrics and Gynecology, The Second Affiliated Hospital and Yuying Children's Hospital of Wenzhou Medical University, Wenzhou, Zhejiang 325027, P.R. China E-mail: jiang_s@mercer.edu

Key words: octreotide, paclitaxel, conjugate, ovarian cancer, resistance, somatostatin the resistance of ovarian cancer against taxol. The findings also shed some new light on the mechanisms underlying the development of resistance to taxol by ovarian cancer cells.

\section{Introduction}

Ovarian cancer is the most severe gynecologic malignancy, causing 114,000 deaths a year globally. In the USA alone, an estimated 23,000 women are diagnosed with ovarian cancer each year and the 5-year survival rate is merely $30 \%$ (1). In the United States, ovarian cancer represents $3 \%$ of all the new cancer cases in women, and accounts for $5 \%$ of all the cancer deaths (2). The high mortality is partly due to the frequent resistance of ovarian cancer to chemotherapy regimens. Paclitaxel combined with platinum remains to be the first line chemotherapy for ovarian cancer. Paclitaxel is a small molecule cytotoxin targeting tubulin and has strong cytostatic and apoptotic effects. Unfortunately, while most patients initially respond to this combined chemotherapy, the majority of these (up to 75\%) will eventually relapse within 18 months with many having drug resistant disease (3). Ovarian cancer cells develop drug resistance through different pathways depending on the drug used (4). Multiple mechanisms can mediate the development of paclitaxel resistance, including changes in: i) the regulation or repair of the primary target of the drug (DNA, microtubule); ii) drug retention (increased efflux or decreased uptake); iii) drug inactivation or sequestration; and iv) signaling pathways that affect cell cycle/apoptosis. Paclitaxel is known to be transported by the ATP-dependent efflux pump P-glycoprotein (multidrug resistance, MDR) and upregulation of MDR has been associated with clinical drug resistance to various agents $(5,6)$.

There is an imperative need for the development of new treatment modalities to improve the management of ovarian cancer patients. Switch to alternative drugs with different therapeutic mechanisms is one strategy to overcome the resistance against the presently used drugs. However, limited success has been achieved with the use of second line chemotherapy following the recurrence of ovarian cancer or the resistance to the first 
line drugs (7). This failure is often caused by the activation of 'generic' resistance mechanism against multiple drugs sharing a specific feature. Rationalized design and targeted chemotherapy using modified drugs equipped with new features to avoid the resistance of cancer cells may potentially enhance the drug efficacy and reduce the toxicity of cancer therapies.

SST is a cyclic polypeptide hormone that is found in most human organs and tissues. SST has a broad range of cellular functions such as inhibition of secretion and blocking of cell proliferation and cell survival $(8,9)$. Natural somatostatin (SST) has limited clinical applications because of its low selectivity and short half-life. However, somatostatin analogue (SSTA) is widely applied and has been shown to have more powerful effects and a longer half-life. It has been shown that SSTA is able to inhibit the proliferation of neuroendocrine tumors in vitro as well as tumor growth in vivo (10-14). The specific somatostatin receptor (SSTR), with five subtypes, mediates the functions of SSTA. Two or more receptor subtypes, particularly SSTR2 are often detected in ovarian cancers $(15,16)$ and most types of other tumors $(17,18)$. It is known that SSTR2 mediates the inhibition of cell proliferation via the activation of Ras-, Rapl- and B-Raf-dependent extracellular signal-regulated kinase 2 (Erk2) $(11,12,19)$. Octreotide (OCT) is the most widely used SSTA in clinical applications. OCT was found to exhibit the highest binding affinity to SSTR2 and subsequently inhibit the activity of tyrosine phosphatase and the proliferation of SSTR2-expressing cells $(20,21)$. In previous studies, we detected the expression of SSTR2 in SKOV3/DDP by quantitative PCR and showed that OCT could inhibit ovarian cancer proliferation and promote apoptosis via the cell surface SSTR2. Furthermore, OCT could reverse cisplatin resistance through inhibition of MRP2, EGFR and GST- $\pi$ expressions $(22,23)$.

The mechanisms by which SST and SSTA enhance the paclitaxel sensitivity of resistant ovarian cancer cells remain unclear. OCT might be of practical value in developing tumor tracers and in serving as a carrier of cytotoxic antitumor drugs. The antitumor activity of paclitaxel relies on its capability of promoting tubulin assembly into microtubules and the resultant interference with the G2-M transition of cell cycle $(24,25)$. Huang et al (26) coupled paclitaxel to SSTA and showed that the conjugate displayed an increased cytotoxicity in vitro. Sun et al (27) and Shen et al (28) reported that paclitaxeloctreotide conjugate (POC) could enhance tumor growth inhibition with reduced toxicity in non-small cell lung cancer patients in comparison to unconjugated paclitaxel. The abovementioned evidence suggests the conjugate triggers tumor cell apoptosis mediated by SSTRs and is exclusively toxic to SSTR-expressing cells. Thus, the conjugate could be less toxic to low-SSTR-expressing cells compared with free paclitaxel.

In the present study, we prepared the POC and investigated its function and mechanism for the reversal of drug resistance in a paclitaxel-resistant ovarian cancer cell line. The findings shed new light on the mechanisms of drug resistance and may provide useful information for the development of better treatment approach for ovarian cancer patients.

\section{Materials and methods}

The synthesis of POC. Direct synthesis of OCT acetic acid and paclitaxel succinic acid derivatives was prepared for target products. Paclitaxel of $200 \mathrm{mg}$ and succinic anhydride of $300 \mathrm{mg}$ were dried in vacuum for $5 \mathrm{~h}$, dissolved in $5 \mathrm{ml}$ dry pyridine, and mixed for reaction at $30^{\circ} \mathrm{C}$ for $24 \mathrm{~h}$. The reaction products were re-dissolved in $10 \mathrm{ml}$ of acetone and the paclitaxel succinyl anhydride was extracted from solid precipitation in conditions of drying and reduced pressure, followed by adding and stirring with $10 \mathrm{ml}$ of water dropwise. Paclitaxel succinyl anhydride of $25 \mathrm{mg}$, SDPP (N-hydroxysuccinimido diphenyl phosphate) of $30 \mathrm{mg}$ and triethylamine of $30 \mathrm{mg}$ were dissolved in $0.5 \mathrm{ml}$ anhydrous acetonitrile with stirring overnight at room temperature. The preliminary product mixture was followed by vacuum concentration process and then re-dissolved into ethyl acetate. Finally, the target product was successfully recovered by washing and drying process.

Cell culture. Human ovarian cancer cell line A2780 (Institute of Biochemistry and Cell Biology, Chinese Academy of Sciences, Shanghai, China) and A2780/Taxol (Bogoo Biotechnology, Co., Ltd., Shanghai, China) were cultured at $37^{\circ} \mathrm{C}, 5 \% \mathrm{CO}_{2}$ atmosphere and $90 \%$ humidity, in RPMI-1640 medium (Gibco, Carlsbad, CA, USA) with $10 \%$ fetal bovine serum (FBS; Invitrogen, Waltham, MA, USA). The cells were passaged every 2-3 days using 0.25\% trypsin (Sigma-Aldrich, Schnelldorf, Germany). The log-phase cells were collected for further experiment.

Confocal microscopy. To evaluate the targeted binding of POC to SSTR2 positive cells, we observed the internalization of fluorescein-labeled POC into A2780/Taxol cells at different times. A2780/Taxol cells cultured with fluorescein-labeled POC $(10 \mathrm{nmol} / \mathrm{ml})$ were detected by confocal microscope (Olympus FluoView ${ }^{\mathrm{TM}}$ FV1000; Olympus, Tokyo, Japan) at $30 \mathrm{~min}, 2 \mathrm{~h}$ and $8 \mathrm{~h}$ when after preparation of phosphatebuffered saline (PBS) buffer washing 3 times.

Cell proliferation assay. A2780/Taxol cells (Bogoo Biotechnology) in the log-phase were seeded in each well of the 96 -well culture plates and cultured at $37^{\circ} \mathrm{C}$ under a $5 \%$ $\mathrm{CO}_{2}$ atmosphere for $24 \mathrm{~h}$. The cells were incubated in $100 \mu \mathrm{l}$ of medium with paclitaxel $(0,1.25,2.5,5,10$ and $20 \mathrm{nmol} / \mathrm{ml})$, OCT $(0,1.25,2.5,5,10$ and $20 \mathrm{nmol} / \mathrm{ml})$, or POC $(0,1.25$, $2.5,5,10$ and $20 \mathrm{nmol} / \mathrm{ml}$ ). At different time-points, cells were treated with $10 \mu \mathrm{l}$ of the Cell Counting kit-8 (CCK-8; Dojindo Laboratories, Kumamoto Japan) for $3 \mathrm{~h}$. Absorbance (A) was measured on an enzyme-linked immunosorbent assay plate reader. The inhibition rate was calculated using the following formula: Cell proliferation inhibition rate $=$ (average of value A from the control group - the average of value A from the experimental group)/(average of value A from the control group - average of value A from blank controller) x $100 \%$. Resistance index was calculated with the following formula: $\mathrm{IC}_{50}$ of resistant $\mathrm{A} 2780$ cells/ $\mathrm{IC}_{50}$ of parental A2780 cells. All experiments were repeated in triplicate and more than three wells were used for each treatment.

Detection of cell apoptosis. The experiment contained four groups comprising the control, paclitaxel $(10 \mathrm{nmol} / \mathrm{ml})$, OCT $(10 \mathrm{nmol} / \mathrm{ml})$ and POC $(10 \mathrm{nmol} / \mathrm{ml})$. Following treatment for 36h, cell apoptosis was examined using the Annexin V-FITC/PI staining kit (Nanjing KeyGen Biotech, Co., Ltd., Nanjing, 
Table I. Primer sequences for the real-time PCR reaction.

\begin{tabular}{ll}
\hline Objective gene & \multicolumn{1}{c}{ Primer sequence } \\
\hline$\beta$-actin-Forward & GATGACCCAGATCATGTTTGAG \\
$\beta$-actin-Reverse & AGGGCATACCCCTCGTAGAT \\
SSTR2-Forward & CATTTATGTCATCCTCCGCTAT \\
SSTR2-Reverse & TGATTGATGCCATCCACAGT \\
VEGF-Forward & CAGAAGGAGGAGGGCAGAAT \\
VEGF-Reverse & CACAGGATGGCTTGAAGATG \\
MDR1-Forward & GCTGTCAGGTGCCATCAAT \\
MDR1-Reverse & TGGAAGGGAGCGGTGTAA \\
\hline
\end{tabular}

China) according to the instructions provided by the manufacturer. Flow cytometry (FACSVantage SE; BD Biosciences, San Jose, CA, USA) was performed and apoptotic cells were counted for each group of treatment.

Immunocytochemistry. The cells cultured on coverslips in 6-well plates were fixed in $4 \%$ paraformaldehyde for $30 \mathrm{~min}$, washed with PBS for $5 \mathrm{~min}$ and permeabilized with Triton X-100 (Sigma-Aldrich). The cells were incubated with $10 \%$ goat serum for 20 min for blocking. Primary rabbit monoclonal antibody (anti-SSTR2, 1:100; Abcam) was added and the incubation continued overnight at $4^{\circ} \mathrm{C}$ in a humidified chamber. After washing with PBS, HRP-labeled secondary antibody was applied for 30-min incubation. Coverslips were immersed in freshly prepared DAB solution (Dako Denmark A/S, Glostrup, Denmark) for color development. Cells were counterstained with hematoxylin for $10 \mathrm{~min}$ and microscopic observation was performed for the detection of SSTR2 expression.

Real-time PCR. Total RNA was extracted from A2780/Taxol cells treated by conjugate for $48 \mathrm{~h}$ with the use of TRIzol reagents. RNA concentration was measured on a UV spectrophotometer based on the absorbance values at 260 and $280 \mathrm{~nm}$. cDNA was synthesized using $1 \mu \mathrm{g}$ of total RNA according to the instructions provided in the RT-PCR kit (Takara). Designation and sequences of PCR primers (Houzai Co., Tokyo, China) are provided in Table I. Real-time PCR was performed in a LightCycler (Roche Applied Science) under the following conditions: pre- 80 denaturation at $94^{\circ} \mathrm{C}$ for $2 \mathrm{~min}$, then denaturation at $94^{\circ} \mathrm{C}$ for $45 \mathrm{sec}$, annealing at $56^{\circ} \mathrm{C}$ for $45 \mathrm{sec}$, extension at $72^{\circ} \mathrm{C}$ for $45 \mathrm{sec}$. Fold of difference relative to the reference gene ( $\beta$-actin) was determined by conversion of $2^{-\Delta \Delta \mathrm{CT}} . \Delta \Delta \mathrm{CT}=\left(\mathrm{CT}_{\text {objective gene }}-\mathrm{CT}_{\text {reference gene }}\right)$ of experimental group - $\left(\mathrm{CT}_{\text {objective gene }}-\mathrm{CT}_{\text {reference gene }}\right)$ of control group.

Western blot analysis. Following our previously established method (29), A2780/Taxol cells treated by conjugate for $48 \mathrm{~h}$ were lysed using modified RIPA lysis buffer (1\% NP-40, $0.25 \%$ deoxycholic acid, $50 \mathrm{mM}$ Tris- $\mathrm{HCl} \mathrm{pH} 7.4,1 \mathrm{mM}$ EDTA, $150 \mathrm{mM} \mathrm{NaCl}, 1 \mathrm{mM} \mathrm{NaF}, 1 \mathrm{~g} / \mathrm{ml}$ leupeptin, $1 \mathrm{mM}$ PMSF, $1 \mathrm{mM}$ sodium orthovanadate, $2 \mathrm{~g} / \mathrm{ml}$ pepstatin and $1 \mathrm{~g} / \mathrm{ml}$ aprotinin). Cell lysates were boiled in the loading buffer (3.3\% glycerin, 1\% SDS, $20 \mathrm{mM}$ TRIS, pH 6.8, $23 \mathrm{mM}$ $\beta$-mercaptoethanol freshly added and $0.4 \mathrm{mg} / \mathrm{ml}$ bromophenol blue). Proteins were separated in precast gradient SDS-PAGE (4-20\%) and transferred to polyvinylidenfluorid (PDVF) membranes (Bio-Rad Laboratories, Hercules, CA, USA), and then incubated with specific primary antibodies for $2 \mathrm{~h}$ at room temperature, followed by $1 \mathrm{~h}$ of incubation with appropriate HRP-conjugated secondary antibodies. Western blot analyses were performed by using primary antibodies against SSTR2 $(1: 1,000)$, IGF-1 (1:600), VEGF $(1: 1,000)$. The antigen-antibody complexes in western blot analysis were detected with an enhanced chemiluminescence detection system (Amersham Biosciences, Pittsburgh, PA, USA). Specific protein bands were visualized after autoradiography. The intensity of each protein band was quantified by using image analysis software and normalized against corresponding $\beta$-actin that was detected by anti- $\beta$-actin antibody $(1: 2,000)$.

Statistical analysis. Statistical analysis was performed using the SPSS 16.0 software. Data are expressed as the means \pm SD. The ANOVA and Student's t-test was used for comparison of the drug-treated and drug-untreated controls. A P<0.05 was considered to indicate a statistically significant result.

\section{Results}

Synthesis of POC. Direct synthesis of OCT acetic acid and paclitaxel succinic acid derivatives was performed as described in Materials and methods. As shown in Fig. 1, the process consisted of sequential synthesis of the following four chemicals: i) N-hydroxysuccinimido diphenyl phosphate; ii) paclitaxel succinyl anhydride; iii) N-hydroxy paclitaxel succinyl anhydride; and iv) POC.

SSTR2 expression in A2780/Taxol cells. In order to confirm the SSTR2 expression in the cell model, we performed immunocytochemistry using the specific antibody against SSTR2. As shown in Fig. 2, A2780/Taxol cell membranes display strong positive staining.

Internalization of fluorescein-labeled POC in A2780/ Taxol cells. The specific fluorescein were visible mainly along the cell surface of the A2780/Taxol cells at $30 \mathrm{~min}$ of culture, whereas part of the denser fluorescent grains appeared into the cytoplasm at $2 \mathrm{~h}$. Moreover, fluorescent grains were visibly distributed through the cytoplasm, and many grains were concentrated around cell nucleus at $8 \mathrm{~h}$ (Fig. 3). These results strongly suggested that POC has a favorable and specific binding targeted to SSTR2-positive cells, which resulted from the SSTR2-mediated internalization in A2780/Taxol cells.

Effect of POC on A2780/Taxol cell proliferation. The A2780/ Taxol cells were round, cytoplasm-rich and grew vigorously under normal conditions. Without treatment, cells were transparent, spread evenly, and with smooth and complete edges and had similar sizes and shapes. Following POC treatment for $24 \mathrm{~h}$, the number of adherent normal cells decreased, and the cell-cell space became larger. Some cells appear to be condensed, darker and displayed morphological features of apoptosis including shrinkage, foaming and formation of apoptotic bodies. 

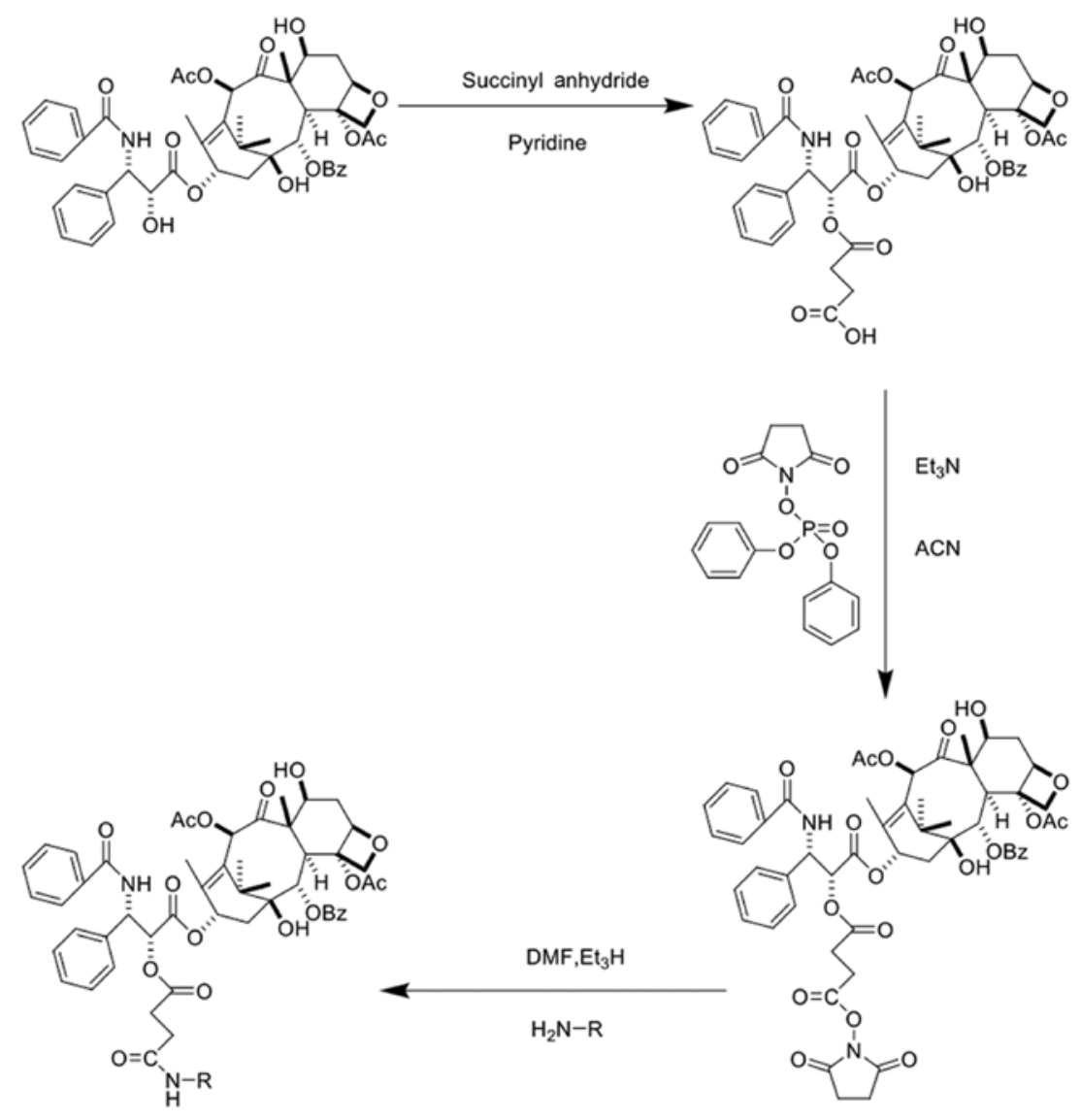

R: D-Phe-Cys-Phe-D-Trp-Lys-Thr-Cys-Thr-ol

Figure 1. Procedures for the synthesis of POC. The process consisted of synthesis of the following four chemicals: i) N-hydroxysuccinimido diphenyl phosphate (SDPP); ii) paclitaxel succinyl anhydride; iii) N-hydroxy paclitaxel succinyl anhydride; iv) POC.

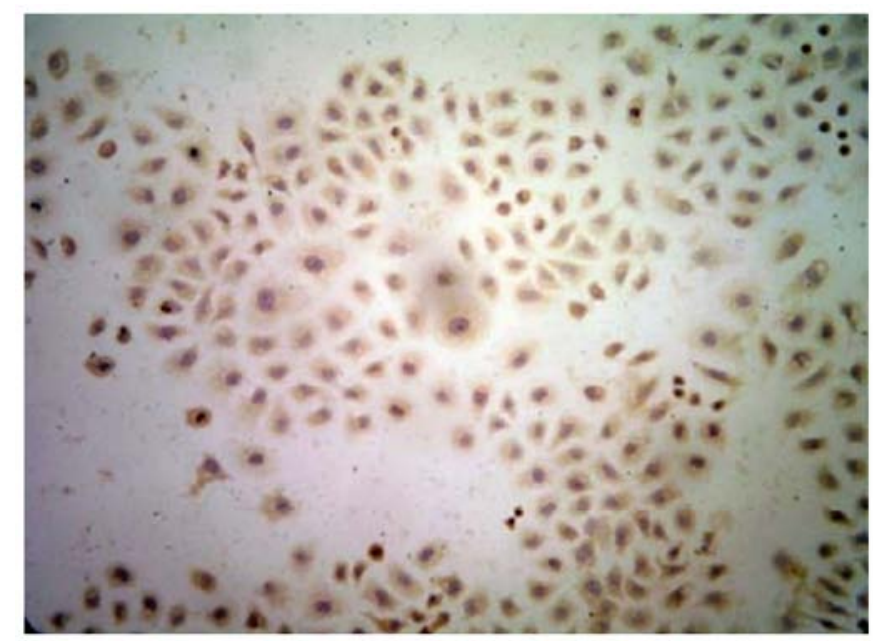

Figure 2. Expression of SSTR2 in A2780/Taxol cells. Following immunocytochemistry SSTR2 expression was observed under high power microscopic view (magnification, x40). A2780/Taxol cells were composed of blue nuclei and brown membrane surface with granular structure, indicating SSTR2 expression on the A2780/Taxol cell membrane. Cell counting indicated that $>80 \%$ of A2780/Taxol cells were SSTR2-positive.

As the treatment time prolonged, cell growth became slow and there were increased numbers of floating cells and
Table II. Inhibition rate of POC on A2780/Taxol cell proliferation at the indicated concentration and time.

\begin{tabular}{lcccc}
\hline Groups & $\begin{array}{c}\text { POC } \\
(\mathrm{nmol} / \mathrm{ml})\end{array}$ & $\begin{array}{c}\text { Time I } \\
(24 \mathrm{~h})\end{array}$ & $\begin{array}{c}\text { Time II } \\
(48 \mathrm{~h})\end{array}$ & $\begin{array}{c}\text { Time III } \\
(72 \mathrm{~h})\end{array}$ \\
\hline 1 & 0 & 0 & 0 & 0 \\
2 & $1.25^{\mathrm{a}}$ & $8.83 \pm 0.32$ & $13.28 \pm 0.20$ & $16.35 \pm 0.72^{\mathrm{f}}$ \\
3 & $2.5^{\mathrm{a}, \mathrm{b}}$ & $12.17 \pm 0.42$ & $15.51 \pm 0.93^{\mathrm{f}}$ & $23.61 \pm 1.21^{\mathrm{f}, \mathrm{g}}$ \\
4 & $5.0^{\mathrm{a}-\mathrm{c}}$ & $17.34 \pm 0.27$ & $28.18 \pm 0.15^{\mathrm{f}}$ & $41.18 \pm 1.00^{\mathrm{f}, \mathrm{g}}$ \\
5 & $10.0^{\mathrm{a}-\mathrm{d}}$ & $25.24 \pm 0.87$ & $49.31 \pm 1.49^{\mathrm{f}}$ & $60.50 \pm 1.99^{\mathrm{f}, \mathrm{g}}$ \\
6 & $20.0^{\mathrm{a}-\mathrm{e}}$ & $34.80 \pm 0.62$ & $53.27 \pm 2.08^{\mathrm{f}}$ & $65.48 \pm 2.17^{\mathrm{f}, \mathrm{g}}$ \\
\hline
\end{tabular}

${ }^{\mathrm{a}} \mathrm{P}<0.05$ vs. group $1 ;{ }^{\mathrm{b}} \mathrm{P}<0.05$ vs. group $2 ;{ }^{\mathrm{c}} \mathrm{P}<0.05$ vs. group 3 ; ${ }^{\mathrm{d}} \mathrm{P}<0.05$ vs. group 4 ; ${ }^{\mathrm{e}} \mathrm{P}<0.05$ vs. group 5 ; ${ }^{\mathrm{f}} \mathrm{P}<0.05$ vs. Time I; ${ }^{\mathrm{g}} \mathrm{P}<0.05$ vs. Time II.

cell debris. According to the dose-effect curves of paclitaxel on A2780/Taxol and A2780 cells, the calculated resistance index (RI) of A2780/Taxol cell to paclitaxel was 28.33. POC exhibited an enhanced inhibitory effect on A2780/Taxol cell proliferation, with the calculated resistance index (RI) reaching 4.2 (Fig. 4). Notably, the POC inhibited proliferation 

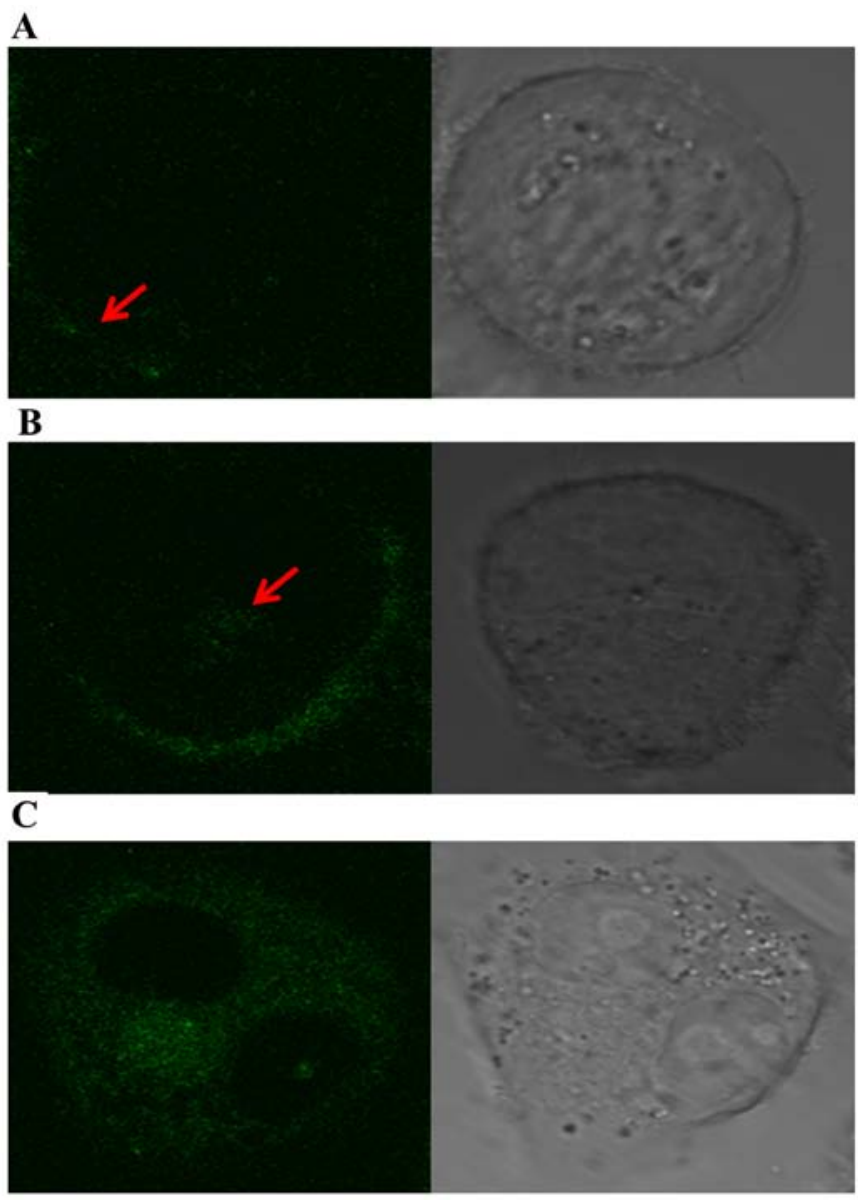

Figure 3. Confocal microscopy of fluorescein-labeled POC in A2780/Taxol cells. After $30 \mathrm{~min}$ of incubation with $10 \mathrm{nmol} / \mathrm{ml}$ fluorescein-labeled POC, fluorescein is mainly located at the membrane of the cells (arrowheads) (A), and upon incubation for $2 \mathrm{~h}$, fluorescent labels appeared in the cytoplasm (arrowhead) (B). Fluorescent grains were visibly distributed through the cytoplasm of the cells and many grains were concentrated around the nucleus (C).

at the indicated time $(24,48$ and $72 \mathrm{~h})$ in a concentrationdependent manner $(\mathrm{P}<0.05$; Table II and Fig. 5).

Enhanced apoptotic effect of POC in A2780/Taxol cells. Compared to the control group, increased apoptosis was observed in paclitaxel $(10 \mathrm{nmol} / \mathrm{ml})$, OCT $(10 \mathrm{nmol} / \mathrm{ml})$ and POC $(10 \mathrm{nmol} / \mathrm{ml})$ groups $(\mathrm{P}<0.05)$. Both the effect of POC group and that of OCT group were much more powerful than the paclitaxel group $(\mathrm{P}<0.05)$. In addition, the effect of POC group was more powerful than the OCT group $(\mathrm{P}<0.05)$ (Fig. 6).

Alteration of SSTR2, MDR1 and VEGF mRNA expression following drug treatment. To investigate the mechanism responsible for the enhanced effects of POC, mRNA was isolated, and SSTR2, MDRI and VEGF mRNA expression was determined following treatment with POC. As shown in Fig. 7, SSTR 2 mRNA was detected in each group, but there is no difference between the various concentrations $(\mathrm{P}>0.05)$. Compared to the control group, the expression of both $M D R 1$ and VEGF mRNA decreased in a dose-dependent manner following $48 \mathrm{~h}$ of treatment with POC $(\mathrm{P}<0.05)$, indicating their involvement in the POC-mediated cell effects.
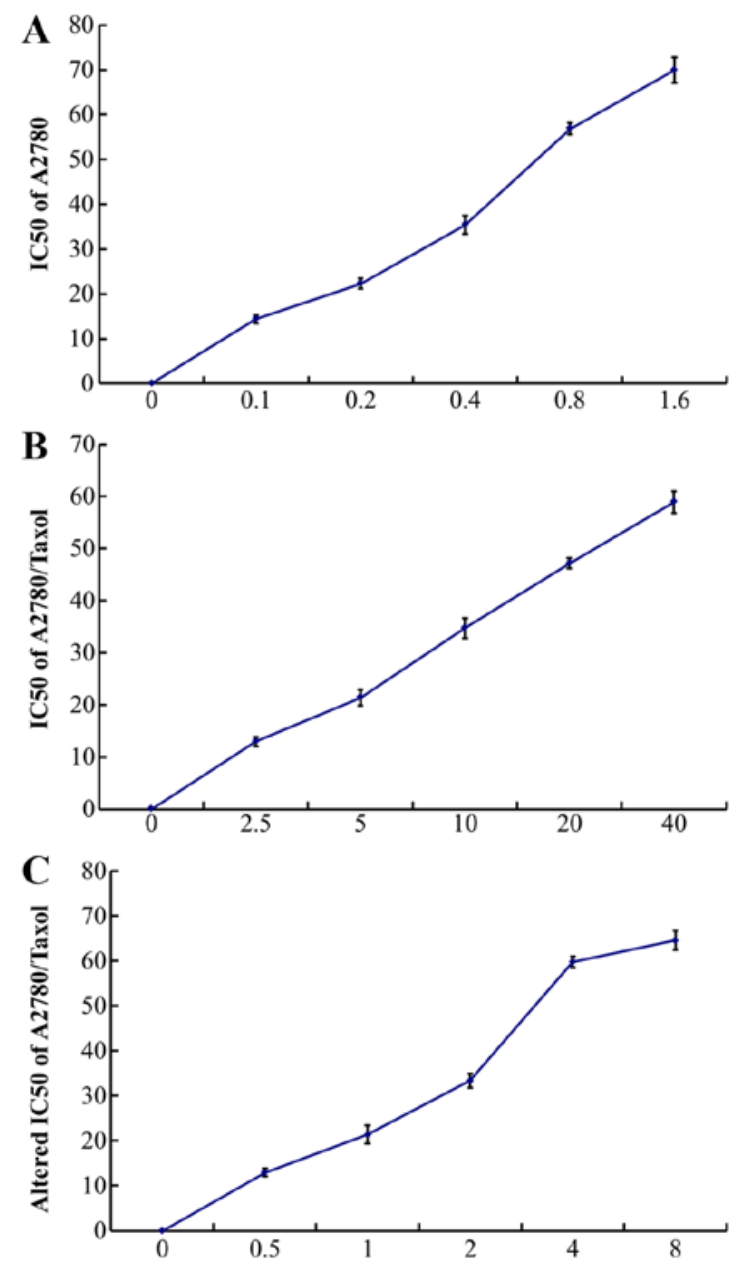

Figure 4. The dose-effect curves of paclitaxel in A2780 and A2780/Taxol cells. The cell viability was examined by CCK- 8 assay. Inhibition concentration $(50 \%)\left(\mathrm{IC}_{50}\right)$ of paclitaxel was $0.94 \mathrm{nmol} / \mathrm{ml}$ in A2780 cells $(\mathrm{A})$, and $26.56 \mathrm{nmol} / \mathrm{ml}$ in A2780/Taxol cells (B), respectively. The calculated resistance index (RI) of A2780/Taxol cell to paclitaxel was 28.33. The altered $\mathrm{IC}_{50}$ and $\mathrm{RI}$ reached 3.95 and $4.2 \mathrm{nmol} / \mathrm{ml}(\mathrm{C})$, respectively, after treatment with conjugate for $48 \mathrm{~h}$.

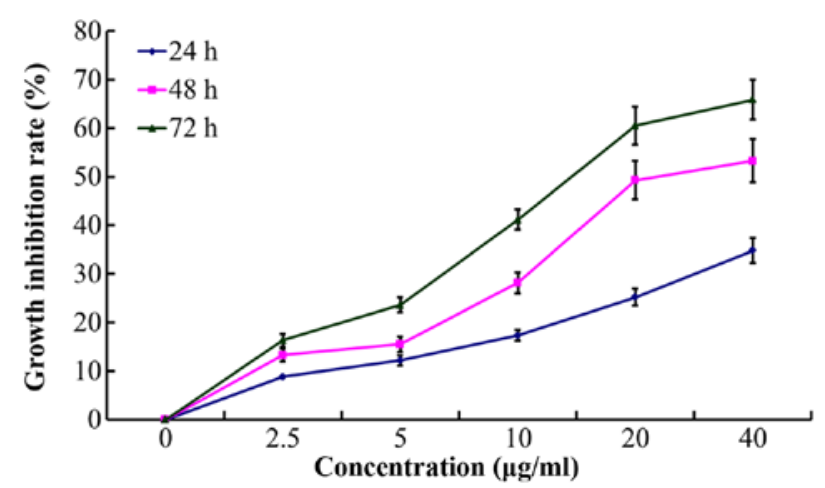

Figure 5. The inhibitory effect of POC in A2780/Taxol cells. Cells were treated with $\mathrm{POC}$ at the indicated concentration and time. POC exhibited an enhanced inhibitory effect on A2780/Taxol cell proliferation (24, 48 and $72 \mathrm{~h})$ in a time- and concentration-dependent manner $(\mathrm{P}<0.05)$.

Alterations of SSTR2, MDR1 protein expression in A2780/Taxol cells. Western blotting was performed to determine how POC may affect the protein levels of SSTR2, 
$\mathbf{A}$
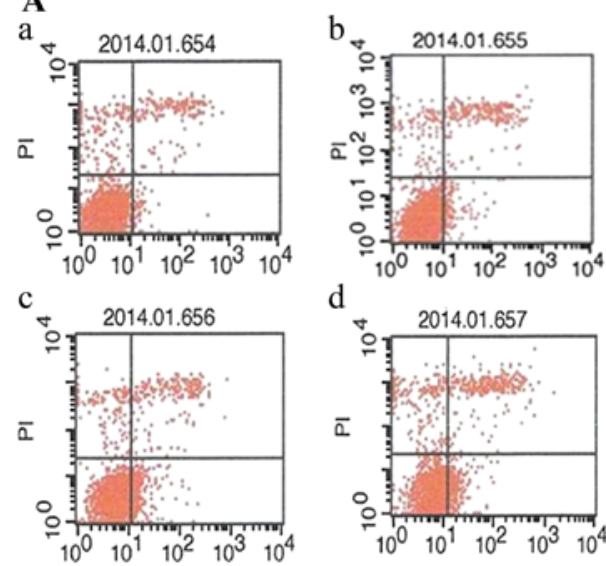

$\mathrm{d}$
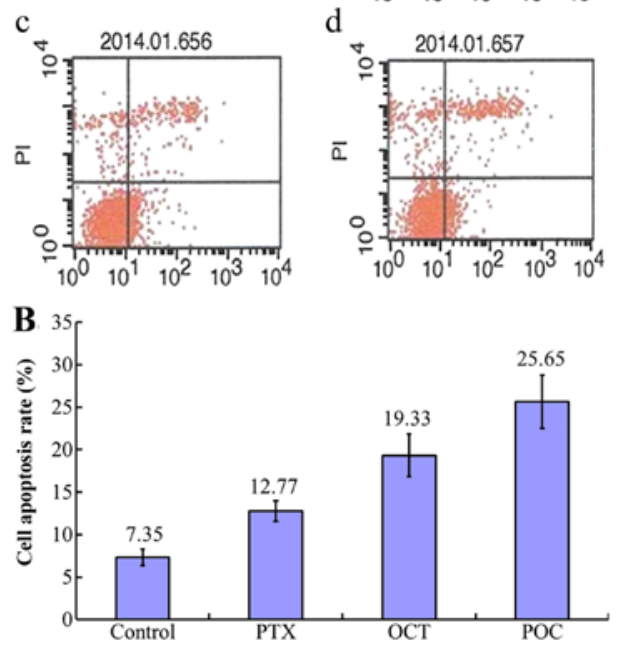

Figure 6. Effects of paclitaxel, octreotide and POC on A2780/Taxol cell apoptosis. Following treatment, cell apoptosis was measured by Annexin V-FITC/ PI staining (A). The levels of cell apoptosis followed an order of control (a), paclitaxel (b), OCT (c) and POC (d), from low to high. POC group and OCT group displayed more apoptosis than the paclitaxel group $(\mathrm{P}<0.05)(\mathrm{B})$. In addition, the apoptotic effect of POC group was stronger than that of the OCT group $(\mathrm{P}<0.05)$.

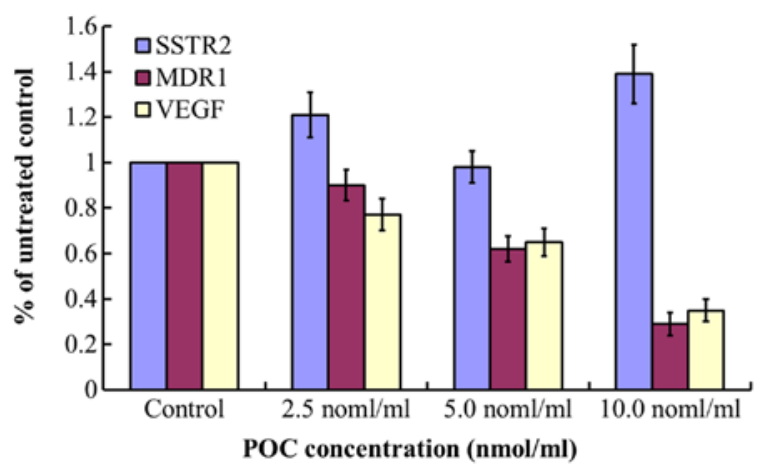

Figure 7. Effect of OCT on $S S T R 2, M D R 1$ and $V E G F$ mRNA expression in A2780/Taxol cells. SSTR2, MDR1 and VEGF mRNA expression was determined following treatment with $\mathrm{POC}$ for $48 \mathrm{~h}$. Compared to the control group, $M D R 1$ and $V E G F$ mRNA levels decreased in a dose-dependent manner $(\mathrm{P}<0.05)$, but the SSTR2 mRNA levels remained stable.

MDR1 and VEGF. The intensity of protein bands was read by densitometry and the standardized results with $\beta$-tubulin are summarized in Table III. The results indicated that following $48 \mathrm{~h}$ of treatment, both proteins were decreased in a dosedependent manner $(\mathrm{P}<0.05)$ (Fig. 8).

\section{Discussion}

Feasibility and simplicity are key factors to be considered for the design of synthesis strategy. Huang et al (26) firstly reported that paclitaxel succinyl anhydride reacts with



Figure 8. Effect of POC on SSTR2 and MDR1 protein expression in A2780/ Taxol cells. Western blotting indicated that SSTR2 and MDR1 proteins were significantly decreased in a dose-dependent manner following treatment with POC $(\mathrm{P}<0.05)$. The results were standardized with the density of correspondent bands of $\beta$-actin that was used as a protein loading control.

OCT from solid phase synthesis through the catalysis of Benzotriazol-1-yl-oxytripyrrolidino-phosphonium hexafluorophosphate (PyBOP) and POC is obtained after dissociating from resin. However, OCT resin complex in this method is not available in the market and the catalyst PyBOP is expensive which bring us difficulty in synthesis and application of POC. In this study, we adopted a new synthesis approach, which overcomes the difficulty of unavailable OCT resin complex and expensive catalyst. The process included the sequential synthesis of N-hydroxysuccinimido diphenyl phosphate, paclitaxel succinyl anhydride, $\mathrm{N}$-hydroxy succinyl acid ester and POC. Using this method, POC can be synthesized in a large amount from cheap reagent Diphenyl N-succinimid-ster (SDPP). This has opened a new route for mass production by pharmaceutical industry, and thus, opening the door for large scale clinical trials on this bioactive agent.

Paclitaxel combined with platinum remains the first line chemotherapy in the treatment of ovarian cancer. However, due to resistance, it often fails to cure patients. Therefore, the reversal of paclitaxel resistance in ovarian cancer and increased sensitivity to paclitaxel-based chemotherapy drugs is a crucial issue. Our earlier study showed that chemotherapy agent combined with OCT could markedly inhibit the proliferation and promote apoptosis of resistant ovarian cancer cells. This combination of the two single drugs has significant synergistic action $(22,23)$. Furthermore, studies on synthesized POC in lung cancer cells have shown its cytotoxicity in vitro and in vivo (26-28). The thought for increased efficacy of OCT-conjugated taxol was based on the hypothesis that after binding to SSTR, through SSTR endocytosis, OCT-conjugated taxol would internalize into the cytosol of SSTR-expressing tumor cells and therefore increasing the intracellular concentration of paclitaxel. The present study of confocal microscopy also supported this opinion. In addition, this may lead to a decreased toxicity of taxol in non-SSTR-expressing cells (26).

Our current data suggested that POC inhibited A2780/Taxol cell proliferation, increased the chemotherapeutic sensitivity 
Table III. Effect of POC on expression of SSTR2, MDR1 and VEGF protein in A2780/Taxol cells.

\begin{tabular}{lcccc}
\hline Protein & Control & $2.5 \mathrm{nmol} / \mathrm{ml}$ & $5.0 \mathrm{nmol} / \mathrm{ml}$ & $10.0 \mathrm{nmol} / \mathrm{ml}$ \\
\hline SSTR2 & 1 & $0.4860 .047^{\mathrm{a}}$ & $0.3480 .038^{\mathrm{a}, \mathrm{b}}$ & $0.2210 .033^{\mathrm{a}-\mathrm{c}}$ \\
MDR1 & 1 & $0.6390 .062^{\mathrm{a}}$ & $0.3670 .057^{\mathrm{a}, \mathrm{b}}$ & $0.2420 .027^{\mathrm{a}-\mathrm{c}}$ \\
VEGF & 1 & $0.7710 .055^{\mathrm{a}}$ & $0.5680 .035^{\mathrm{a}, \mathrm{b}}$ & $0.3350 .030^{\mathrm{a}-\mathrm{c}}$ \\
$\beta$-tubulin & 1 & 1 & 1 & 1 \\
\hline
\end{tabular}

${ }^{\mathrm{a}} \mathrm{P}<0.05$ vs. the control group; ${ }^{\mathrm{b}} \mathrm{P}<0.05$ vs. the $2.5 \mathrm{nmol} / \mathrm{ml}$ group; ${ }^{\mathrm{c}} \mathrm{P}<0.05 \mathrm{vs}$. the $5 \mathrm{nmol} / \mathrm{ml}$ group.

of paclitaxel and reversed chemotherapy resistance. Moreover, we found that the mRNA levels of SSTR2 were not altered but the mRNA levels of $M D R l$ and $V E G F$ were significantly reduced following POC treatment, whereas, the expression of SSTR2, MDR1 and VEGF protein appeared to be decreased by conjugate treatment. The relatively stable levels of SSTR2 mRNA and significant reduction in protein indicated its post-translational regulation. Interestingly, Huang et al (26) reported that short-term OCT treatment could lead to SSTR2 desensitization, resulting in a reduced inhibitory effect on hepatocellular carcinoma cells by OCT. However, long-term OCT treatment effectively inhibited the development and growth of hepatocellular carcinoma cells probably via resensitization and upregulation of SSTR2. This discrepancy for short-term effect on SSTR2 protein levels may be due to the different characteristics of hepatocellular carcinoma cells and ovarian cancer cells, the different expression levels of the receptor, and the higher intracellular concentration that the conjugate may potentially achieve. Nevertheless, our results have pointed to the possibility that POC may exert its effect through decreasing SSTR2 expression.

MDR1 was found to decrease the intracellular paclitaxel concentration, leading to a reduced or loss of drug function in ovarian cancer cells $(30,31)$. This study demonstrated a decreased MDR1 expression in A2780/Taxol cells by the treatment with POC on both mRNA and protein levels, suggesting that MDR1 may be involved in POC-mediated inhibition of cell proliferation and reversal of paclitaxel resistance. Vascular endothelial growth factor-A (VEGF-A, commonly known as VEGF) is a key pro-angiogenic factor that plays a crucial role in tumor expansion (32). Akiyama et al (33) observed that VEGF secreted from tumors upregulated MDR1 through the activation of VEGFR2 and Akt. MDR1 upregulation, via the VEGF-VEGFR pathway in the tumor microenvironment, is one of the mechanisms of drug resistance acquired by tumor endothelial cells. This study demonstrated a decrease of VEGF mRNA and protein expression in A2780/Taxol cells by POC, suggesting that one action of this agent may be through the downregulation of MDR1 and inhibition of VEGF expression. More detailed studies are required to elucidate how the POC could inhibit the expression of VEGF and the downstream genes.

The present study demonstrates the effects of POC on A2780/Taxol cells and explored the possible mechanism mediated by SSTR2, MDR1 and VEGF. The study introduces a potential chemotherapeutic reagent for ovarian cancer therapy. However, the mechanism of the metabolism, transportation and pharmacological dynamics of POC from the extracellular to intracellular departments remain unclear. Future mechanistic and in vivo studies are required for a better understanding of this novel agent.

\section{Acknowledgements}

The present study was supported by the Youth Projects of Jiangsu Provincial Health Department (no. Q201305), the Science and Technology Research Project of Nanjing City (no. 201201054), a Pre-research Project for National Natural Science Foundation of Southeast University (no. KJ2010493), and the Scientific Research Project of Southeast University (no. 3290003101).

\section{References}

1. Syrios J, Banerjee S and Kaye SB: Advanced epithelial ovarian cancer: From standard chemotherapy to promising molecular pathway targets - where are we now? Anticancer Res 34: 2069-2077, 2014

2. Siegel R, Ward E, Brawley O and Jemal A: Cancer statistics, 2011: The impact of eliminating socioeconomic and racial disparities on premature cancer deaths. CA Cancer J Clin 61: 212-236, 2011.

3. McGuire WP, Hoskins WJ, Brady MF, Kucera PR, Partridge EE, Look KY, Clarke-Pearson DL and Davidson M: Cyclophosphamide and cisplatin compared with paclitaxel and cisplatin in patients with stage III and stage IV ovarian cancer. N Engl J Med 334: 1-6, 1996.

4. Sherman-Baust CA, Becker KG, Wood Iii WH, Zhang Y and Morin PJ: Gene expression and pathway analysis of ovarian cancer cells selected for resistance to cisplatin, paclitaxel, or doxorubicin. J Ovarian Res 4: 21, 2011.

5. Szakács G, Paterson JK, Ludwig JA, Booth-Genthe C and Gottesman MM: Targeting multidrug resistance in cancer. Nat Rev Drug Discov 5: 219-234, 2006.

6. Gottesman MM, Fojo T and Bates SE: Multidrug resistance in cancer: Role of ATP-dependent transporters. Nat Rev Cancer 2: 48-58, 2002.

7. Markman M: Combination versus sequential cytotoxic chemotherapy in recurrent ovarian cancer: Time for an evidence-based comparison. Gynecol Oncol 118: 6-7, 2010

8. Theodoropoulou M and Stalla GK: Somatostatin receptors: From signaling to clinical practice. Front Neuroendocrinol 34: 228-252, 2013

9. Watt HL, Kharmate $\mathrm{G}$ and Kumar U: Biology of somatostatin in breast cancer. Mol Cell Endocrinol 286: 251-261, 2008.

10. Yano T, Radulovic S, Osuga Y, Kugu K, Yoshikawa H, Taketani Y and Schally AV: Inhibition of human epithelial ovarian cancer cell growth in vitro by somatostatin analog RC-160. Oncology 59 (Suppl 1): 45-49, 2000.

11. Pyronnet S, Bousquet C, Najib S, Azar R, Laklai H and Susini C: Antitumor effects of somatostatin. Mol Cell Endocrinol 286: 230-237, 2008

12. Robbins RJ: Somatostatin and cancer. Metabolism 45 (Suppl 1): 98-100, 1996. 
13. Susini $\mathrm{C}$ and Buscail L: Rationale for the use of somatostatin analogs as antitumor agents. Ann Oncol 17: 1733-1742, 2006.

14. Oberg K: Cancer: Antitumor effects of octreotide LAR, a somatostatin analog. Nat Rev Endocrinol 6: 188-189, 2010.

15. Halmos G, Sun B, Schally AV, Hebert F and Nagy A: Human ovarian cancers express somatostatin receptors. J Clin Endocrinol Metab 85: 3509-3512, 2000.

16. Jones RH, Reubi JC, Millan D and Vasey P: Octreotide: An active agent in epithelial ovarian carcinoma? Lancet Oncol 5: 251-253, 2004.

17. Barnett P: Somatostatin and somatostatin receptor physiology. Endocrine 20: 255-264, 2003.

18. Annaratone L, Volante M, Asioli S, Rangel N and Bussolati G: Characterization of neuroendocrine tumors of the pancreas by real-time quantitative polymerase chain reaction. A methodological approach. Endocr Pathol 24: 83-91, 2013.

19. Pawlikowski M: The incidence of somatostatin receptors in human neoplasms in the light of ex vivo-in vitro studies. Endokrynol Pol 57: 238-243, 2006 (in Polish).

20. Murphy E, Prommer EE, Mihalyo M and Wilcock A: Octreotide. J Pain Symptom Manage 40: 142-148, 2010.

21. Hua YP, Yin XY, Peng BG, Li SQ, Lai JM, Liang HZ and Liang LJ: Mechanisms and influence of octreotide-induced regulation of somatostatin receptor 2 on hepatocellular carcinoma. Chemotherapy 55: 312-320, 2009.

22. Shen Y, Ren M, Shi Y, Zhang Y and Cai Y: Octreotide enhances the sensitivity of the SKOV3/DDP ovarian cancer cell line to cisplatin chemotherapy in vitro. Exp Ther Med 2: 1171-1176, 2011.

23. Shen Y, Ren ML, Shi YH, Zhang YX and Cai YL: Octreotide is the novel alternative for chemosensitivity enhancement of ovarian cancer cells SKOV3/DDP to cisplatin in vitro and in nude mice in vivo. Eur J Gynaecol Oncol 33: 584-590, 2012.

24. Chu JJ, Chen KD, Lin YL, Fei CY, Chiang AS, Chiang CD and Lai YK: Taxol induces concomitant hyperphosphorylation and reorganization of vimentin intermediate filaments in $9 \mathrm{~L}$ rat brain tumor cells. J Cell Biochem 68: 472-483, 1998.
25. Horwitz SB: Mechanism of action of taxol. Trends Pharmacol Sci 13: 134-136, 1992.

26. Huang CM, Wu YT and Chen ST: Targeting delivery of paclitaxel into tumor cells via somatostatin receptor endocytosis. Chem Biol 7: 453-461, 2000.

27. Sun ML, Wei JM, Wang XW, Li L, Wang P, Li M and Yi CH: Paclitaxel-octreotide conjugates inhibit growth of human non-small cell lung cancer cells in vitro. Exp Oncol 29: 186-191, 2007.

28. Shen H, Hu D, Du J, Wang X, Liu Y, Wang Y, Wei JM, Ma D, Wang P and Li L: Paclitaxel-octreotide conjugates in tumor growth inhibition of A549 human non-small cell lung cancer xenografted into nude mice. Eur J Pharmacol 601: 23-29, 2008

29. Shen Y, Ren ML, Feng X, Cai YL, Gao YX and Xu Q: An evidence in vitro for the influence of bisphenol $A$ on uterine leiomyoma. Eur J Obstet Gynecol Reprod Biol 178: 80-83, 2014.

30. Lukyanova NY: Characteristics of homocysteine-induced multidrug resistance of human MCF-7 breast cancer cells and human A2780 ovarian cancer cells. Exp Oncol 32: 10-14, 2010.

31. Schöndorf T, Kurbacher CM, Göhring UJ, Benz C, Becker M, Sartorius J, Kolhagen H, Mallman P and Neumann R: Induction of MDR1-gene expression by antineoplastic agents in ovarian cancer cell lines. Anticancer Res 22: 2199-2203, 2002.

32. Ebos JM and Kerbel RS: Antiangiogenic therapy: Impact on invasion, disease progression, and metastasis. Nat Rev Clin Oncol 8: 210-221, 2011.

33. Akiyama K, Ohga N, Hida Y, Kawamoto T, Sadamoto Y, Ishikawa S, Maishi N, Akino T, Kondoh M, Matsuda A, et al: Tumor endothelial cells acquire drug resistance by MDR1 up-regulation via VEGF signaling in tumor microenvironment. Am J Pathol 180: 1283-1293, 2012. 